\title{
Compassion Fatigue among Healthcare Personnel in Acute Care Contexts: An Integrative Review
}

\author{
Kam Ki Stanley LAM \\ School of Nursing \\ Tung Wah College \\ Hong Kong, China \\ stanleylam@twc.edu.hk
}

\author{
Shuk Yu Maria HUNG \\ School of Nursing \\ Tung Wah College \\ Hong Kong, China \\ mariahung@twc.edu.hk
}

\begin{abstract}
Healthcare workers in acute care settings experience considerable emotional exhaustion on a daily basis, which might lead to the manifestation of compassion fatigue that adversely impacts their wellbeing. There has been an increasing awareness in understanding compassion fatigue on healthcare workers recently, but the literature within this area remains ambiguous due to the use of different terminology. This integrative review aims to synthesize the existing research knowledge of the manifestation of compassion fatigue and the related concepts in acute care contexts. A total of 27 full-text research articles were retrieved for analysis. The interpretation of the selected articles yielded four main categories, which included the prevalence, risk factors, protective factors, and consequences regarding compassion fatigue among healthcare workers. These findings provide an outline for decision makers of healthcare organizations to formulate a strategic plan for helping healthcare workers to cope with compassion fatigue in everyday work and disaster events.
\end{abstract}

Keywords-compassion fatigue; stress disorders, post-traumatic; secondary traumatic stress; acute care contexts

\section{INTRODUCTION}

Healthcare workers who care for patients on a daily basis are exposed to various occupational hazards, including injuries and infections [1]. In addition to the direct physical hazards, the negative emotional and psychological effects resulted from working with traumatized populations are attracting an increasing awareness from the healthcare field [2]. To identify the emotional and psychological effects, the concept of compassion fatigue $(\mathrm{CF})$, which was first coined by Joinson [3] as a "unique form of burnout" among healthcare workers, could interfere with their ability to nurture. Figley [1] elaborated the description in a more explicit manner and depicted CF as the state of exhaustion with regards to the negative repercussions from the intentions and behaviors to help a traumatized person. Although direct traumatization is not involved, unmanaged $\mathrm{CF}$ could have profound consequences for the wellbeing of the healthcare workers in both physical and emotional aspects. It is revealed that the cumulative effect of $\mathrm{CF}$ could lead to a wide range of negative outcomes, which included headaches, stomachaches, sleep disturbance, anxiety, depression, and increased substance use [4]. Given the highly stressful work environments that saturated with critically ill and traumatized patients, researchers have recently shown an increased interest in exploring the occurrence of CF in acute care contexts [5]. As a result of the practice contexts, evidence suggests that healthcare workers in acute care contexts are at additional risk for developing $\mathrm{CF}$ [6]. It is noted from the existing literature that the concept of $\mathrm{CF}$ has been described in various terminologies, some of which included secondary traumatization, secondary traumatic stress, and vicarious traumatization [7]. Despite the subtle difference of the concepts of these terms, these terms were often used interchangeably with $\mathrm{CF}$ in studies related to the cumulative effects of exposure to traumatic on healthcare workers [8,9]. However, very few studies have systematically integrated and synthesized the literature on $\mathrm{CF}$ and the related terminologies [5], which could result in ambiguity and misinterpretation in the understanding of the existing evidence [10]. This integrative review intends to contribute to this growing area of research by scrutinizing, appraising, and synthesizing the international evidence on the key issues of $\mathrm{CF}$ and the related concepts among healthcare personnel in acute care contexts. By addressing the available evidence comprehensively, it is anticipated that this review could provide grounds for future researchers pertain to $\mathrm{CF}$.

\section{METHODS}

\section{A. Search strategy and selection criteria}

To enable a comprehensive understanding of the manifestation of $\mathrm{CF}$, this review has incorporated quantitative, qualitative, and mixed methods data. Integrating evidence from different research methods and designs would probably enhance the utility and relevance of the findings of a literature review to inform policy and practice [11]. A comprehensive literature search was conducted following the adapted PRISMA (Preferred Reporting Items for Systematic Reviews and MetaAnalyses) guidelines [12] on various wide-ranging electronic databases, including CINAHL, EBSCOhost, EMBASE, MEDLINE, ProQuest, PsycINFO, and PubMed. The review considered qualitative and quantitative studies published in the period from 2000 to 2016 September that addressed issues of compassion fatigue and the related concepts. The search terms used for the retrieval of literature were as follows: [compassion fatigue OR secondary traumatization OR secondary traumatic stress OR vicarious traumatization*] AND [healthcare personnel OR healthcare worker* OR healthcare professional* OR healthcare specialist*]. A list of 363 articles was retrieved after the search. Seven additional articles were identified 
through manual searching of journals. Articles identified to be potentially relevant and eligible for the review were retrieved, while three duplicate articles across databases were excluded. The subsequent set of 367 articles was comprehensively reviewed in full-text for the relevance to the aims of this review. In addition, reference lists of the relevant studies and publications were scrutinized for relevant citations. Eligibility of the publications was determined by assessing the design, participant, and outcome measure of the studies: (1) Types of study: Studies of quantitative, qualitative, or mixed method design that evaluated or presented primary data on the CF or related concepts of healthcare workers were included; (2) Types of participant: Studies of healthcare workers in acute care contexts were included; and (3) Types of outcome measure: Studies of consequences and influences on healthcare workers were included. Publications were excluded in this review if they were (1) not in the English language; (2) not published in peerreviewed journals; (3) not referred specifically to acute care contexts; or (4) conducted in mental health settings. Disagreements upon the inclusion or exclusion of articles in the review process were resolved by discussion between the authors. Of the 367 articles, 337 were excluded based on the inclusion and exclusion criteria. Three articles were further excluded after assessing full-text due to ineligibility. The remaining 27 articles were identified to have fulfilled the search criteria and served the aims of this review. Thus, these 27 articles were retrieved for data analysis. A flow diagram illustrating the literature search process is shown in Figure 1.

\section{B. Quality appraisal}

The included articles were critically assessed for the relevance of evidence and quality of reporting by employing the Gough's Weight of Evidence framework [13]. The framework focuses on determining the preponderance of evidence through assessing the integrity, fitness, and relevance of the study and findings in addressing research questions with an overall score of the weight of evidence [14]. Discrepancies regarding the weight of articles in the quality appraisal process were resolved by discussion between the authors.

\section{Data extraction and analysis}

Data were extracted from the retrieved publications to provide information including year of publication, geographical source, research design, study population, data collection instrument, and research purpose. The findings of each study were interpreted by adopting a thematic synthesis approach [15]. This data analysis and synthesis method consist of three stages, of which target on developing meaning units, descriptive themes, and analytical themes from the primary findings from the involved articles. The findings of this literature review are presented as tabular and narrative summary since the formal statistical analysis was infeasible with the high heterogeneity of the study design of the retrieved studies.

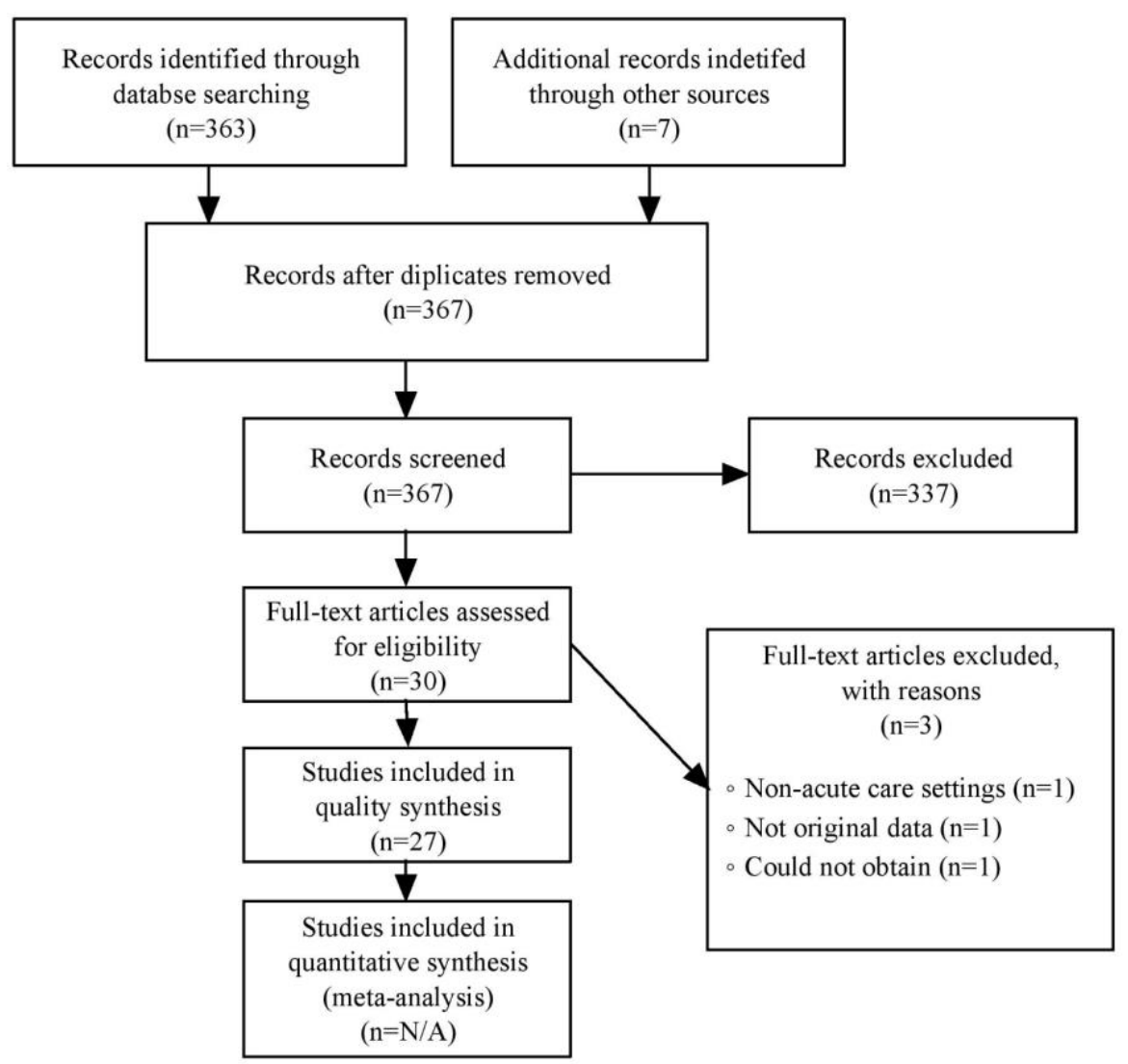

Figure 1: PRISMA flow diagram of the literature search and review process 


\section{RESULTS}

In order to evaluate the current trends and characteristics of studies regarding $\mathrm{CF}$ on healthcare workers in acute care contexts, the scope of research and overall features of the retrieved articles were reviewed. An overview of the 27 studies retrieved that related to $\mathrm{CF}$ and healthcare workers in acute care contexts is presented in Table 1. The interpretation of the selected articles yielded five main categories that addressed the areas of paramount importance in the existing literature regarding $\mathrm{CF}$ among healthcare workers in acute care contexts, which included the prevalence, risk factors, protective factors, and consequences of $\mathrm{CF}$.

\section{A. Prevalence of $C F$}

One of the major objectives of this review is to identify the prevalence of $\mathrm{CF}$ shown by healthcare workers in acute care contexts. It is apparent from the results of the retrieved studies that there was a glaring discrepancy between the reported frequencies of $\mathrm{CF}$ among healthcare workers. Of the eight studies that reported the occurrence of symptoms of $\mathrm{CF}$, the incidence rate ranged from $5 \%$ to $86 \%$ [17,21,22,27,33,39,40]. Among the wide-ranging results, the study from Hooper et al. [27] stands out for reporting a considerably high prevalence of $\mathrm{CF}$ among the studied population. In their study which investigates the prevalence of $\mathrm{CF}$ in emergency nurses, nearly $86 \%(n=92 / 114)$ of the participants shared symptoms of CF. The finding was echoed in a small-scale study by DominguezGomez and Rutledge [22] which set out to explore the prevalence of $\mathrm{CF}$ among emergency nurses. Over $85 \%$ $(n=57 / 67)$ of the emergency nurses surveyed in the study indicated moderate to high levels of $\mathrm{CF}$ about their work. As with studies of $\mathrm{CF}$ and professions, the incidence of CF is not evenly distributed within occupational groups in acute care contexts. The retrieved articles generally reported a rate of $\mathrm{CF}$ among nurses higher than that of the physicians and social workers. Of the five articles studied the incidences of $\mathrm{CF}$ on nurses, the frequency ranged from over $80 \%$ [22,27], more than $60 \%(n=292 / 464)[17]$, approximately $15 \%(n=17 / 106)[41]$, to $7 \%$ [39]. The nurses from these studies were emergency nurses $[22,27]$, obstetric nurses [17], nursing staff from various settings (Yoder, 2010), and trauma nurses [39] respectively. However, the paucity of studies might hinder the understanding of the association between work nature and development of CF. Further research regarding $\mathrm{CF}$ prevalence among healthcare professionals from diverse disciplines is worthwhile.

\section{B. Risk factors of $C F$}

Several studies have revealed that the length of employment was considered a major risk factor for $\mathrm{CF}$ among healthcare workers in acute care contexts. For example, the study conducted by Badger et al. [16] stated that the length of employment was negatively correlated with the incidence and level of CF among the surveyed social workers. Similar results were noted in studies among nurses. Von Rueden et al. [39] in their study on trauma nurses further explained that the association between length of employment and the tendency in developing CF could result from the inability of staff with less clinical experience in coping with the emotional contagion in caring traumatized patients.
It is noted in the literature that the relationship with coworkers in the workplace might also affect the level and severity of CF on healthcare workers in acute care contexts. For example, a previous study that investigated the influence of a car bombing event in Ireland on healthcare workers of a multidisciplinary trauma and recovery team explored that the high level of CF-related emotional distress was associated with the suboptimal relationship with co-workers [20]. Consistent findings were reported in another study on trauma team workers, in which the participated trauma nurses reflected the negative correlation of perceived teamwork in the workplace and the reported incidence and level of CF [39].

The workload on healthcare workers was reported to be the strongest organizational predictor of $\mathrm{CF}$ within acute care contexts. Findings from several sources have identified the increased fan frequency and level of CF-associated with a heavy workload. For example, in their mixed method study about the prevalence and severity of CF among obstetrics nurses in the United States, Beck and Gable [17] addressed the burden from work as a crucial determinant of $\mathrm{CF}$ amongst the studies population. The pediatric nurses from a qualitative study conducted by McGibbon et al. [35] also depicted the experience of vicarious sharing of patients' suffering within a stressful working environment. In addition, the study by Frank and Adkinson [24] pointed out that the burden and stress induced by large-scale emergencies could initiate a significant increase in the levels of risk of $\mathrm{CF}$.

\section{Protective factors of $C F$}

Concerning the protective factors of $\mathrm{CF}$, a variety of attributes and conditions were reported to be able to significantly mitigate the risk of indirect traumatization of healthcare workers within acute care contexts. Consider that the development of $\mathrm{CF}$ results from the vicarious sharing of another's traumatized experience, an emotional detachment of the healthcare workers was reported in several studies to be effective in mitigating the likelihood for developing CF. Badger et al.'s cross-sectional study [16] of the level of secondary traumatic stress in hospital social workers showed that emotional separation was associated with the reduced vulnerability of CF exposure. In participants who were able to maintain objectivity and modulate emotional proximity with patients, a reduced tendency of CF development was reported. In accordance with this finding, a study presented similar results and addressed that the higher the level of emotional separation of the participants, the lower the level of $\mathrm{CF}$ from patient caring [39].

Interpersonal interaction in workplaces plays a critical role in both the causes and prevention of CF. While the poor cowork relationship would increase the risk of exposure of healthcare workers to $\mathrm{CF}$, the close connection among coworkers was found to be significant in mitigating the tendency of developing CF. The importance of team spirit in the workplace was mentioned in the study by Collins and Long [20], which showed that the strong team spirit in workplaces could effectively lower the risk for CF among the workers. It was explained that the workers would obtain social support 
Table 1. Cross-tabulation illustrating study designs, populations, aims of the study, and Weight of Evidence

\begin{tabular}{|c|c|c|c|c|c|c|}
\hline $\begin{array}{l}\text { Reference } \\
\text { number }\end{array}$ & $\begin{array}{l}\text { Author(s) } \\
\text { and Year }\end{array}$ & Country & Study design & Populations & Aims of study & $\begin{array}{l}\text { The weight } \\
\text { of Evidence } \\
\text { a }\end{array}$ \\
\hline 16 & $\begin{array}{l}\text { Badger et al., } \\
2008\end{array}$ & United States & $\begin{array}{l}\text { Quantitative, cross- } \\
\text { sectional survey }\end{array}$ & $\begin{array}{l}121 \text { hospital social workers } \\
\text { (response rate } 73 \% \text { ) }\end{array}$ & $\begin{array}{l}\text { To explore the predictive contributions of empathy, } \\
\text { emotional separation, occupational stress, and social } \\
\text { support for producing STS in hospital social workers }\end{array}$ & H H H - H \\
\hline 17 & $\begin{array}{c}\text { Beck \& } \\
\text { Gable, } 2012\end{array}$ & United States & $\begin{array}{l}\text { Mixed methods, } \\
\text { convergent parallel } \\
\text { design }\end{array}$ & $\begin{array}{l}\text { 464 labor and delivery } \\
\text { nurses } \\
\text { (response rate } 15 \% \text { ) }\end{array}$ & $\begin{array}{l}\text { To determine the prevalence and severity of secondary } \\
\text { traumatic stress in labor and delivery nurses and to explore } \\
\text { nurses' descriptions of their experiences attending } \\
\text { traumatic births }\end{array}$ & H H H - H \\
\hline 18 & Bride, 2007 & United States & $\begin{array}{l}\text { Quantitative, cross- } \\
\text { sectional survey }\end{array}$ & $\begin{array}{l}282 \text { social workers, } 56 \text { of } \\
\text { them were from healthcare } \\
\text { settings (response rate } \\
49.6 \% \text { ) }\end{array}$ & $\begin{array}{l}\text { To investigate the prevalence of STS in a sample of social } \\
\text { workers by examining the frequency of individual } \\
\text { symptoms; the frequency with which diagnostic criteria for } \\
\text { PTSD are met; and the severity of STS levels }\end{array}$ & H H H - H \\
\hline 19 & $\begin{array}{l}\text { Burtson \& } \\
\text { Stichler, } \\
2010\end{array}$ & United States & $\begin{array}{l}\text { Quantitative, } \\
\text { correlational study }\end{array}$ & 126 nurses & $\begin{array}{l}\text { To examine the relations of compassion satisfaction, nurse } \\
\text { job satisfaction, stress, burnout, and compassion fatigue to } \\
\text { nurse caring }\end{array}$ & H H H - H \\
\hline 20 & $\begin{array}{l}\text { Collins \& } \\
\text { Long, } 2003\end{array}$ & Ireland & $\begin{array}{l}\text { Mixed method, } \\
\text { cross-sectional } \\
\text { survey }\end{array}$ & $\begin{array}{l}13 \text { members of a } \\
\text { multidisciplinary trauma and } \\
\text { recovery team }\end{array}$ & $\begin{array}{l}\text { To investigate the effects on caregivers across time, } \\
\text { working with people traumatized as a result of the Omagh } \\
\text { bombing; coping strategies that caregivers found beneficial } \\
\text { in reducing compassion fatigue and burnout, and factors } \\
\text { that enhanced compassion satisfaction }\end{array}$ & H M M - M \\
\hline 21 & $\begin{array}{c}\text { Craig \& } \\
\text { Sprang, } 2010\end{array}$ & United States & $\begin{array}{l}\text { Quantitative, cross- } \\
\text { sectional survey }\end{array}$ & $\begin{array}{l}532 \text { clinical psychology and } \\
\text { clinical social work } \\
\text { (response rate } 27.1 \% \text { ) }\end{array}$ & $\begin{array}{l}\text { To investigate the impact of using evidence-based } \\
\text { practices on compassion fatigue, burnout, and compassion } \\
\text { satisfaction in a random, national sample of self-identified } \\
\text { trauma specialists }\end{array}$ & H H H - H \\
\hline 22 & $\begin{array}{l}\text { Dominguez- } \\
\text { Gomez et al., } \\
2009 \\
\end{array}$ & United States & $\begin{array}{l}\text { Quantitative, } \\
\text { exploratory } \\
\text { comparative study }\end{array}$ & $\begin{array}{l}67 \text { emergency nurses } \\
\text { (response rate } 63 \% \text { ) }\end{array}$ & To investigate the prevalence of STS in emergency nurses & H H H - H \\
\hline 23 & $\begin{array}{l}\text { Flarity et al., } \\
2013\end{array}$ & United States & $\begin{array}{l}\text { Quantitative, a pre- } \\
\text { /posttest design }\end{array}$ & $\begin{array}{l}59 \text { emergency nurses } \\
\text { (response rate } 80 \% \text { ) }\end{array}$ & $\begin{array}{l}\text { To examine the treatment effectiveness of a multifaceted } \\
\text { education program to decrease } \mathrm{CF} \text { and } \mathrm{BO} \text { symptoms and } \\
\text { increase compassion satisfaction of emergency nurses } \\
\text { participating in the training. }\end{array}$ & H H H - H \\
\hline
\end{tabular}




\begin{tabular}{|c|c|c|c|c|c|c|}
\hline 24 & $\begin{array}{c}\text { Frank \& } \\
\text { Adkinson, } \\
2007\end{array}$ & United States & $\begin{array}{l}\text { Quantitative, cross- } \\
\text { sectional survey }\end{array}$ & $\begin{array}{l}55 \text { public health nurses aged } \\
40-60 \\
\text { (response rate } 11 \%)\end{array}$ & $\begin{array}{l}\text { To identify the levels of risk of CF in middle-aged female } \\
\text { nurses who worked during the } 2004 \text { Florida hurricanes. }\end{array}$ & H M M - M \\
\hline 25 & $\begin{array}{l}\text { Gleichgerrch } \\
\text { \& Decety, } \\
2013\end{array}$ & Argentina & $\begin{array}{l}\text { Quantitative, cross- } \\
\text { sectional survey }\end{array}$ & 7854 physicians & $\begin{array}{l}\text { To determine which aspects of empathy are associated with } \\
\text { positive or negative outcome in practicing physicians }\end{array}$ & H H H - H \\
\hline 26 & $\begin{array}{l}\text { Goldbort et } \\
\text { al., } 2011\end{array}$ & United States & $\begin{array}{l}\text { Qualitative, } \\
\text { phenomenology }\end{array}$ & 9 intrapartum nurses & $\begin{array}{l}\text { To describe the essence of nine nurses' participation in an } \\
\text { unexpected/ traumatic birthing process to ascertain what } \\
\text { impact this experience had on the nurse. }\end{array}$ & H M M - M \\
\hline 27 & $\begin{array}{l}\text { Hooper et al., } \\
2010\end{array}$ & United States & $\begin{array}{l}\text { Quantitative, cross- } \\
\text { sectional survey }\end{array}$ & $\begin{array}{l}114 \text { nurses, } 49 \text { of them were } \\
\text { emergency nurses } \\
\text { (response rate } 83 \% \text { ) }\end{array}$ & $\begin{array}{l}\text { To explore the prevalence of compassion satisfaction, } \\
\text { burnout, and compassion fatigue among emergency nurses } \\
\text { and nurses in other selected inpatient specialties. }\end{array}$ & H H H - H \\
\hline 28 & $\begin{array}{c}\text { Jonsson \& } \\
\text { Halabi, } 2006\end{array}$ & Jordan & $\begin{array}{l}\text { Qualitative, } \\
\text { phenomenology }\end{array}$ & 25 emergency nurses & $\begin{array}{l}\text { To identify causes of post-traumatic stress symptoms and } \\
\text { their relationship with everyday work stress exposure. }\end{array}$ & H H H - H \\
\hline 29 & $\begin{array}{l}\text { Komachi et } \\
\text { al., } 2012\end{array}$ & Japan & $\begin{array}{l}\text { Quantitative, cross- } \\
\text { sectional survey }\end{array}$ & $\begin{array}{l}338 \text { hospital nurses } \\
\text { (Response rate } 52.1 \% \text { ) }\end{array}$ & $\begin{array}{l}\text { To evaluate the prevalence and factors associated with STS } \\
\text { among general hospital nurses }\end{array}$ & H H H - H \\
\hline 30 & $\begin{array}{l}\text { Laposa et al., } \\
2003\end{array}$ & Canada & $\begin{array}{l}\text { Quantitative, Cross- } \\
\text { sectional survey }\end{array}$ & $\begin{array}{l}51 \text { emergency workers }(73 \% \\
\text { are nurses / doctor) }\end{array}$ & $\begin{array}{l}\text { To determine the association between sources of } \\
\text { workplace stress and PTSD symptoms. }\end{array}$ & H H H - H \\
\hline 31 & $\begin{array}{l}\text { Lee et al., } \\
2005\end{array}$ & Taiwan & $\begin{array}{l}\text { Quantitative, cross- } \\
\text { sectional survey }\end{array}$ & $\begin{array}{l}26 \text { nurses from SARS team } \\
\text { in the emergency department }\end{array}$ & $\begin{array}{l}\text { To identify staff stress and coping strategies among a } \\
\text { SARS team of nursing staff during the outbreak. }\end{array}$ & M M M - M \\
\hline 32 & $\begin{array}{l}\text { Maiden et al., } \\
2011\end{array}$ & United States & Mixed methods & 205 critical care nurses & $\begin{array}{l}\text { To examine the previously untested relationships between } \\
\text { moral distress, CF, perceptions about medication errors, } \\
\text { and their characteristics. }\end{array}$ & H H H - H \\
\hline 33 & $\begin{array}{c}\text { Markwell \& } \\
\text { Wainer, } 2009\end{array}$ & $\begin{array}{l}\text { Australia and } \\
\text { New Zealand }\end{array}$ & $\begin{array}{l}\text { Quantitative, cross- } \\
\text { sectional survey }\end{array}$ & $\begin{array}{l}914 \text { junior physicians } \\
\text { (response rate } 22 \% \text { ) }\end{array}$ & $\begin{array}{l}\text { To investigate the health and well-being of junior doctors, } \\
\text { and understand the specific pressures encountered by } \\
\text { them. }\end{array}$ & H M M - M \\
\hline 34 & $\begin{array}{l}\text { McGarry et } \\
\text { al., } 2013\end{array}$ & Australia & $\begin{array}{l}\text { Quantitative, cross- } \\
\text { sectional survey }\end{array}$ & $\begin{array}{l}56 \text { healthcare workers in } \\
\text { burn total care unit, } \\
\text { including nurses, physicians, } \\
\text { allied health (response rate } \\
82 \%)\end{array}$ & $\begin{array}{l}\text { To investigate the impact of regular exposure to pediatric } \\
\text { medical trauma on multidisciplinary teams in a pediatric } \\
\text { hospital and the relationships between psychological } \\
\text { distress, resilience and coping skills. }\end{array}$ & H H H - H \\
\hline 35 & $\begin{array}{l}\text { McGibbon et } \\
\text { al., } 2010\end{array}$ & Canada & $\begin{array}{l}\text { Qualitative, } \\
\text { ethnography }\end{array}$ & $\begin{array}{l}23 \text { nurses from a pediatric } \\
\text { hospital }\end{array}$ & $\begin{array}{l}\text { To reformulate the nature of stress in nursing, with } \\
\text { attention to important contextual aspects of nurses' } \\
\text { practice }\end{array}$ & H H H - H \\
\hline
\end{tabular}




\begin{tabular}{|c|c|c|c|c|c|c|}
\hline 36 & $\begin{array}{l}\text { Sung et al., } \\
\quad 2012\end{array}$ & Korea & $\begin{array}{l}\text { Quantitative, cross- } \\
\text { sectional survey }\end{array}$ & 142 hospital nurses & $\begin{array}{l}\text { To identify relationships between } \mathrm{CF}, \mathrm{BO} \text {, and turnover } \\
\text { intention in Korean hospital nurses. }\end{array}$ & H H H - H \\
\hline 37 & $\begin{array}{l}\text { Swatzky \& } \\
\text { Enns, } 2012\end{array}$ & Canada & $\begin{array}{l}\text { Quantitative, cross- } \\
\text { sectional survey }\end{array}$ & 261 emergency nurses & $\begin{array}{l}\text { To explore the factors that predict the retention of nurses } \\
\text { working in emergency departments. }\end{array}$ & $\mathrm{H} \mathrm{H} \mathrm{H} \mathrm{-} \mathrm{H}$ \\
\hline 38 & $\begin{array}{l}\text { van der Wath } \\
\text { et al., } 2013\end{array}$ & South Africa & $\begin{array}{l}\text { Qualitative, } \\
\text { phenomenology }\end{array}$ & 11 emergency nurses & $\begin{array}{l}\text { To report a study of emergency nurses' experiences of } \\
\text { caring for survivors of intimate partner violence. }\end{array}$ & H H H - H \\
\hline 39 & $\begin{array}{l}\text { Von Rueden } \\
\text { et al., } 2010\end{array}$ & United States & $\begin{array}{l}\text { Quantitative, cross- } \\
\text { sectional survey }\end{array}$ & $\begin{array}{l}128 \text { trauma nurses (response } \\
\text { rate } 49 \% \text { ) }\end{array}$ & $\begin{array}{l}\text { To evaluate the prevalence of STS in nurses who are } \\
\text { working in a trauma center and to examine the } \\
\text { relationships of exposure to traumatic injuries of others, } \\
\text { coping strategies, and personal and environmental } \\
\text { characteristics to the nurses' development of STS. }\end{array}$ & H H H - H \\
\hline 40 & $\begin{array}{l}\text { Warren et al., } \\
2013\end{array}$ & United States & $\begin{array}{l}\text { Quantitative, cross- } \\
\text { sectional survey }\end{array}$ & $\begin{array}{l}133 \text { surgeons in various } \\
\text { specialties }\end{array}$ & $\begin{array}{l}\text { To examine the experience of STS in surgeons and to } \\
\text { explore the influence of positive psychological factors. }\end{array}$ & H H H - H \\
\hline 41 & Yoder, 2010 & United States & $\begin{array}{l}\text { Quantitative, cross- } \\
\text { sectional survey }\end{array}$ & $\begin{array}{l}106 \text { nurses } \\
\text { (response rate 60\%) }\end{array}$ & $\begin{array}{l}\text { To describe the prevalence of CF among a broad spectrum } \\
\text { of nurses, and to investigate the situations that lead to CF } \\
\text { and methods of coping. }\end{array}$ & H H H - H \\
\hline 42 & $\begin{array}{l}\text { Young et al., } \\
2011\end{array}$ & United States & $\begin{array}{l}\text { Quantitative, } \\
\text { exploratory, } \\
\text { descriptive study }\end{array}$ & 70 heart and vascular nurses & $\begin{array}{l}\text { To determine the prevalence of BO and STS in heart and } \\
\text { vascular nurses. }\end{array}$ & H H H - H \\
\hline
\end{tabular}

STS = Secondary traumatic stress

PTSD = Posttraumatic stress disorder

$\mathrm{CF}=$ Compassion fatigue

$\mathrm{BO}=$ Burnout

SARS $=$ Severe acute respiratory syndrome

a The four corresponding criteria regarding Weight of Evidence (WoE) are:

WoE A: Generic on quality execution of study;

WoE B: Review specific on the appropriateness of method;

WoE C: Review specific on focus/approach to study to review;

WoE D: Overall score of quality of the study

("H" stands for High, "M" stands for Medium, and "L" stands for Low) 
from the camaraderie of the colleagues, of which reinforced their capacity in coping with the secondary stress originated from witnessing the patients' suffering [39].

Despite the fact that caring for traumatized patients is the major cause for healthcare workers in developing $\mathrm{CF}$, the risk could be reduced if staff are able to obtain satisfaction from caring. Compassion satisfaction, which described the satisfaction of healthcare workers from the pleasure in knowing the improvement of condition and recovery of the patient, was reported be able to replace the negative experience during patient caring with the pleasure of patient recovery [20,41]. In addition to compassion satisfaction, the utilization of evidencebased practice in routine practice was reported in Craig and Sprang's study [21] to be effective in ameliorating the level of $\mathrm{CF}$ among healthcare workers in acute care contexts. The researchers addressed that the improved competence and confidence in daily practice via adopting the evidence-based practice in workplaces was the rationale behind the lowered secondary stress of the participants.

\section{Consequences of $C F$}

Compassion fatigue was considered to be associated with a wide range of psychological distress. In the phenomenological study conducted by van der Wath et al. [38], it was revealed that the psychological symptoms of $\mathrm{CF}$ might include sadness, depression, fear, and anger. A mixed method study conducted on obstetrics nurses also listed the symptoms in detail, which included fear, frustration, anger, horror, terror, guilt, shame, numbness, and shock [17]. As suggested by Jonsson and Halabi [28] that nurses generally possess a strong commitment in helping the patients who were critically ill or seriously injured, the sense of powerlessness was reported to be one of the other signs of the psychological distress originated from $\mathrm{CF}$ as well. The feelings of self-blaming and, in more serious cases, selfloathing which originated from the guilt of the inability to help the suffered victims were reported as well in the literature $[17,38]$.

Compassion fatigue not merely affected individuals' psychological well-being, but also resulted in a profound impact on the service delivery of healthcare institutions. Laposa et al. [30] indicated in their study conducted in Canada that the emotional distress from CF was one of the main causes leading to the turnover of emergency nurses. Consistently, a similar finding was reported in Swatzky and Enns's study [37] with the similar setting (Canada) and population (emergency nurses). In addition to resignation, an alternative response of healthcare workers was to move from frontline acute care settings to positions or departments which less direct patient care was involved [17,41]. Moreover, the standard of care might also be adversely affected. For example, a study reported that the participants with a high level of CF might try to avoid from contacting and caring patients in order to prevent further unpleasant secondary trauma, which resulted in the reduced initiative in helping the patients in needs [22]. With the avoidance attitudes and behavior in providing patient care, the quality and standard of care could be seriously affected.

\section{DISCUSSION}

This literature review provides updated evidence about the prevalence, factors, and impacts of CF on healthcare workers in acute care settings. Overall, this review indicates that the number and types of studies regarding $\mathrm{CF}$ among healthcare workers have grown during the past few years, with a particular focus on the use of quantitative designs and methods in understanding the perspective of CF. In investigating the level of $\mathrm{CF}$, it is discovered in this review that a variety of instruments were utilized. Although it is obvious that each instrument would have its strength in assessing CF, absent of a consistent scoring parameter might affect the generalizability of the evidence. Thus, further research within the domain related to $\mathrm{CF}$ might include the evaluation of the instruments used in measuring $\mathrm{CF}$ in order to address the applicability of different tools in assessing $\mathrm{CF}$ and provide guidance for the selection of instruments in future studies.

In view of the prevalence and impact of $\mathrm{CF}$, the results of this review highlighted that nursing staff might be most susceptible to sustain a considerable amount of psychological distress, in terms of $\mathrm{CF}$, in daily practice among healthcare workers from other disciplines. Given the proximal nature of nursing care, there can be little doubt that hospital nurses are frequently exposed to traumatic stressors, such as painful medical procedures and end-of-life scenario, from prolonged and intense contact with traumatized or suffering patients in their everyday work [34]; in fact, it is suggested that emotional exhaustion is an inevitable consequence of patient caring [2]. Despite this, far too little attention has been paid to understanding how healthcare workers establish a balance between caring for others and self-care [43]. Given the gap in the literature, further research on the qualitative analysis of the experience and process of healthcare workers in adapting to the phenomenon of $\mathrm{CF}$ in the course of patient care should be undertaken.

Upon understanding the issue of $\mathrm{CF}$ among healthcare workers of everyday work, the findings of this review raise intriguing questions regarding the nature and extent of compassion stress and emotional exhaustion among frontline responders in the course of large-scale public health emergencies. Considering the immense and widespread impact of disaster events, it is suggested in the literature that healthcare workers would be significantly more susceptible to compassion stress and psychological distress while participating in disaster response when compared with the risk of exposure to traumatic stressors in usual practice [24]. While recent trends in disaster management showcase an increasing concern on addressing survivors' psychological and emotional needs [44], much less attention has been paid to the adverse emotional and psychological influence of disaster to healthcare workers, leading to the inadequacy of planning in the management of $\mathrm{CF}$ among first-line responders [24]. Disaster planners should, therefore, take into account the available organizational supports for frontline staff in coping with compassion stress and emotional disturbance in the course of disaster response and should incorporate proper staff deployment and rotation protocol in designing contingency and disaster response plans. 


\section{LIMITATIONS}

There were several limitations inherent in this review. The main limitation lies in its narrow scope due to the limited studies conducted in assessing CF among healthcare workers. In addition, the composition of participants of the included studies was largely inclined to nurses, of which the findings might not be conclusive in addressing the issue of compassion stress on healthcare professionals other than nurses. A further limitation concerned the range of the study designs. Owing to the heterogeneity of research methods in the included articles, a meta-analysis is not feasible, which might probably affect the robustness of the findings of this review. Without ignoring these limitations, however, it is believed that this literature review could offer invaluable practical insights on the understanding of the issues of CF among healthcare workers in acute settings.

\section{CONCLUSIONS}

Nurses are most susceptible to sustain a profound impact from CF in daily practice. The problem of CF is the result of the interaction between affected individuals and a host of risk factors including those that are intrapersonal, interpersonal, and organizational in nature. It not merely affects individuals' psychological well-being, but also adversely influences the service delivery of healthcare institutions. The findings of this review have contributed to a better understanding of the disparities in the prevalence of $\mathrm{CF}$ among healthcare workers in acute care contexts. The risk factors and the protective factors of CF development were also presented. The associated consequences of CF were addressed in this review as well. Recommendations for practice mainly focus on the better involvement of the organization in supporting the staff in lowering the risk and impact of CF. Further research on evaluating the existing coping strategies of healthcare workers and evaluating the quality of instruments in assessing $\mathrm{CF}$ is recommended.

\section{REFERENCES}

[1] C. R. Figley, Compassion fatigue: coping with secondary traumatic stress disorder. New York: Brunner / Mazel, 1995.

[2] N. Magnavita, "Workplace violence and occupational stress in healthcare workers: a chicken-and-egg situation: results of a 6-year follow-up study," Journal of Nursing Scholarship, vol. 46, no. 5, pp. 366-376, 2004.

[3] C. Joinson, "Coping with compassion fatigue," Nursing, vol. 22, no.1, pp. 116-121, 1992.

[4] S. Slocum-Gori, D. Hemsworth, W. W. Chan, A. Carson and A. Kazanjian, "Understanding compassion satisfaction, compassion fatigue and burnout: a survey of the hospice palliative care workforce," Palliative

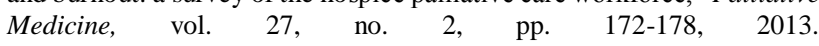
http://dx.doi.org/10.1177/0269216311431311

[5] M. M. van Mol, E. J. Kompanje, D. D. Benoit, J. Bakker and M. D. Nijkamp, "The prevalence of compassion fatigue and burnout among healthcare professionals in intensive care units: a systematic review," Plos One, vol. 10, no. 8, pp. e0136955, 2015. http://dx.doi.org/10.1371/journal.pone.0136955

[6] B. E. Bride, M. Radey and C. R. Figley, "Measuring compassion fatigue," Clinical Social Work Journal, vol. 35, pp. 155-163, 2007. http://dx.doi.org/10.1007/s10615-007-0091-7

[7] S. K. Coetzee and H. C. Klopper, "Compassion fatigue within nursing practice: a concept analysis," Nursing and Health Sciences, vol. 12, no. 2, pp. 235-243, 2010. http://dx.doi.org/10.1111/i.1442-2018.2010.00526.x
[8] C. R. Figley, Secondary traumatic stress self-care issue for clinicians, researchers, and educators. Baltimore: Sidran Press, 1999

[9] M. A. Wagaman, J. M. Geiger, C. Shockley and E. A. Segal, "The role of empathy in burnout, compassion satisfaction, and secondary traumatic stress among social workers," Social Work, vol. 60, no. 3, pp. 201-209, 2015. http://dx.doi.org/10.1093/sw/swv014

[10] S. R. Jenkins and S. Baird, "Secondary traumatic stress and vicarious trauma: a validational study," Journal of Traumatic Stress, vol. 15, no. 5, pp. 423-432, 2002. http://dx.doi.org/10.1023/A:1020193526843

[11] M. Dixon-Woods, S. Bonas and A. Booth, "How can systematic reviews incorporate qualitative research? A critical perspective," Qualitative

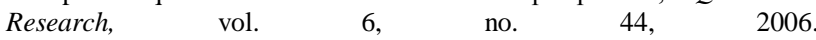
http://dx.doi.org/10.1177/1468794106058867

[12] D. Moher, A. Liberati, J. Tetzlaff and D. G. Altman, "Preferred reporting items for systematic reviews and meta-analyses: the PRISMA statement," Annals of Internal Medicine, vol. 151, no. 4, pp. 264-269, 2009. http://dx.doi.org/10.7326/0003-4819-151-4-200908180-00135

[13] D. Gough, “Assessing quality in applied and practice-based educational research: A framework for discussion," Review of Australian research in education: counterpoints on the quality and impact of educational research-a special issue of the Australian Educational Researcher, vol. 6, pp. 89-104, 2005. http://dx.doi.org/10.1080/02671520701296189

[14] D. Gough, S. Oliver and J. Thomas, An introduction to systematic reviews. London: Sage Publications Ltd, 2012.

[15] J. Thomas and A. Harden, "Methods for the thematic synthesis of qualitative research in systematic reviews," BMC Medical Research Methodology, vol. 8, pp. 1-10, 2008. http://dx.doi.org/10.1186/14712288-8-45

[16] K. Badger, D. Royse and C. Craig, "Hospital social workers and indirect trauma exposure: an exploratory study of contributing factors," Health and Social Work, vol. 33, no. 1, pp. 63-71, 2008. http://dx.doi.org/10.1093/hsw/33.1.63

[17] C. T. Beck and R. K. Gable , "A mixed methods study of secondary traumatic stress in labor and delivery nurses," Journal of Obstetric Gynecologic, and Neonatal Nursing, vol. 41, no. 6, pp. 747-760, 2012. http://dx.doi.org/10.1111/j.1552-6909.2012.01386.x

[18] B. E. Bride, "Prevalence of secondary traumatic stress among social workers," Social Work, vol. 52, no. 1), pp. 63-70, 2007.

[19] P. L. Burtson and J. F. Stichler, "Nursing work environment and nurse caring: relationship among motivational factors," Journal of Advanced Nursing, vol. 66, no. 8, pp. 1819-1831, 2010.

[20] S. Collins and A. Long, "Too tired to care? The psychological effects of working with trauma," Journal of Psychiatric and Mental Health Nursing, vol. 10, no. 1pp. 17-27, 2003. http://dx.doi.org/10.1046/j.13652850.2003.00526.x

[21] C. D. Craig and G. Sprang, G, "Compassion satisfaction, compassion fatigue, and burnout in a national sample of trauma treatment therapists," Anxiety, Stress and Coping, vol. 23, no. 3, pp. 319-339, 2010. http://dx.doi.org/10.1080/10615800903085818

[22] E. Dominguez-Gomez and D. N. Rutledge, "Prevalence of secondary traumatic stress among emergency nurses," Journal of Emergency Nursing, vol. 35, no. 3, pp. 199-204, 2009. http://dx.doi.org/10.1016/j.jen.2008.05.003

[23] K. Flarity, J. E. Gentry and N. Mesnikoff, "The effectiveness of an educational program on preventing and treating compassion fatigue in emergency nurses," Advanced Emergency Nursing Journal, vol. 35, no. 3, 2013. http://dx.doi.org/10.1097/TME.0b013e31829b726f

[24] D. I. Frank and L. F. Adkinson, “A developmental perspective on risk for compassion fatigue in middle-aged nurses caring for hurricane victims in Florida," Holistic Nursing Practice, vol. 21, no. 2, pp. 55-65, 2007. http://dx.doi.org/10.1097/01.HNP.0000262018.49550.5a

[25] E. Gleichgerrcht and J. Decety, "Empathy in clinical practice: how individual dispositions, gender, and experience moderate empathic concern, burnout, and emotional distress in physicians," PloS one, vol. 8, no. 4, pp. e61526, 2013.

[26] J. Goldbort, A. Knepp, C. Mueller and M. Pyron, "Intrapartum nurses' lived experience in a traumatic birthing process," The American journal of maternal child nursing, vol. 36, no. 6, pp. 373-380, 2011. 
[27] C. Hooper, J. Craig, D. R. Janvrin, M. A. Wetsel and E. Reimels, "Compassion satisfaction, burnout, and compassion fatigue among emergency nurses compared with nurses in other selected inpatient specialties," Journal of Emergency Nursing, vol. 36, no. 5, pp. 420-427, 2010. http://dx.doi.org/10.1016/j.jen.2009.11.027

[28] A. Jonsson and J. Halabi, "Work related post-traumatic stress as described by Jordanian emergency nurses," Accident and Emergency Nursing, vol. 14, no. 2, pp. 89-96, 2006. http://dx.doi.org/10.1016/j.aaen.2006.02.001

[29] M. H. Komachi, K. Kamibeppu, D. Nishi and Y. Matsuoka, Y, "Secondary traumatic stress and associated factors among Japanese nurses working in hospitals," International Journal of Nursing Practice, vol. 18, no. 2, pp. 155-163, 2012. http://dx.doi.org/10.1111/j.1440172X.2012.02014.X

[30] J. M. Laposa, L. E. Alden and L. M. Fullerton, "Work stress and posttraumatic stress disorder in ED nurses/personnel," Journal of Emergency Nursing, vol. 29, no. 1, pp. 23-28, 2003. http://dx.doi.org/10.1067/men.2003.7

[31] S. H. Lee, Y. Y. Juang, Y. J. Su, H. L. Lee, Y. H. Lin and C. C. Chao, "Facing SARS: psychological impacts on SARS team nurses and psychiatric services in a Taiwan general hospital," General Hospital Psychiatry, vol. 27, no. 5, pp. 352-358, 2005 http://dx.doi.org/10.1016/j.genhosppsych.2005.04.007

[32] J. Maiden, J. M. Georges and C. D. Connelly, "Moral distress, compassion fatigue, and perceptions about medication errors in certified critical care nurses," Dimensions of critical care nursing: DCCN, vol. 30, no. 6, pp. 339-345, 2011. http://dx.doi.org/10.1097/DCC.0b013e31822fab2a

[33] A. L. Markwell and Z. Wainer, "The health and wellbeing of junior doctors: insights from a national survey," The Medical Journal of Australia, vol. 191, no. 8, pp. 441-444, 2009.

[34] S. McGarry, S. Girdler, A. McDonald, J. Valentine, S. L. Lee, E. Blair, F. Wood and C. Elliott, "Paediatric health-care professionals: relationships between psychological distress, resilience and coping skills," Journal of Paediatrics and Child Health, vol. 49, no. 9, pp. 725-732, 2013. http://dx.doi.org/10.1111/jpc. 12260

[35] E. McGibbon, E. Peter and R. Gallop, “An institutional ethnography of nurses' stress," Qualitative Health Research, vol. 20, no. 10, pp. 13531378, 2010. http://dx.doi.org/10.1177/1049732310375435
[36] K. Sung, Y. Seo and J. H. Kim, "Relationships between compassion fatigue, burnout, and turnover intention in Korean hospital nurses,' Journal of Korean Academy of Nursing. vol. 42, no. 7, pp. 1087-1094, 2012. http://dx.doi.org/10.4040/jkan.2012.42.7.1087

[37] J. V. Swatzky and C. L. Enns, "Exploring the key predictors of retention in emergency nurses," Journal of Nursing Management, vol. 20, no. 5, pp. 696-707, 2012. http://dx.doi.org/10.1111/j.1365-2834.2012.01355.x

[38] A. van der Wath, N. van Wyk and E. Janse van Rensburg, "Emergency nurses' experiences of caring for survivors of intimate partner violence," Journal of Advanced Nursing, vol. 69, no. 10, pp. 2242-2252, 2013. http://dx.doi.org/10.1111/jan.12099

[39] K. T. Von Rueden, K. A. Hinderer, K. A. Mcquillan, M. Murray, T. Logan, B. Kramer, R. Gilmore and E. Friedmann, "Secondary traumatic stress in trauma nurses: prevalence and exposure, coping, and personal/environmental characteristics," Journal of Trauma Nursing, vol. 17, no. 4, pp. 191-201, 2010. http://dx.doi.org/10.1097/JTN.0b013e3181ff2607

[40] A. M. Warren, A. L. Jones, S. Shafi, K. Roden-foreman, M. M. Bennett and M. L. Foreman, "Does caring for trauma patients lead to psychological stress in surgeons?," The Journal of Trauma and Acute Care Surgery, vol. 75, no. 1, pp. 179-184, 2013. http://dx.doi.org/10.1097/TA.0b013e3182984a7d

[41] E. A. Yoder, "Compassion fatigue in nurses," Applied Nursing Research, vol. 23, pp. 191-197, 2010. http://dx.doi.org/10.1016/j.apnr.2008.09.003

[42] J. L. Young, D. M. Derr, V. J. Cicchillo and S. Bressler, "Compassion satisfaction, burnout, and secondary traumatic stress in heart and vascular nurses," Critical Care Nursing Quarterly, vol. 34, no. 3, pp. 227-234, 2011. http://dx.doi.org/10.1097/CNQ.0b013e31821c67d5

[43] R. Newsom, "Compassion fatigue: nothing left to give," Nursing Management, vol. 41, no. 4, pp. 43-45, 2010. http://dx.doi.org/10.1097/01.NUMA.0000370878.55842.e7

[44] E. M. Vernberg, A. M. Steinberg, A. K. Jacobs, M. J. Brymer, P. J. Watson, J. D. Osofsky and J. I. Ruzek, "Innovations in disaster mental health: psychological first aid," Professional Psychology: Research and Practice, vol. 39, no. 4, pp. 381, 2008. http://dx.doi.org/10.1037/a0012663 